\title{
Triatoma infestans in Greater Buenos Aires, Argentina
}

\author{
P Gajate/ ${ }^{+}$, S Pietrokovsky, L Abramo Orrego*, O Pérez*, A Monte*, \\ J Belmonte**, C Wisnivesky-Colli
}

Unidad de Reservorios y Vectores de Parásitos, Departamento de Ciencias Biológicas, Facultad de Ciencias Exactas y Naturales, Universidad de Buenos Aires, Ciudad Universitaria, Pabellón 2, $4^{\circ}$ piso, 1428 Buenos

Aires, Argentina *Ministerio de Salud de la Provincia de Buenos Aires, División de Zoonosis Urbanas, Avellaneda, Argentina **Municipalidad de Florencio Varela, Florencio Varela, Argentina

The Health Administration Agencies of many municipalities in Greater Buenos Aires (GBA) receive frequent reports on triatomines in houses. The aim of this work was to identify and describe the dispersal foci of Triatoma infestans in an urban neighborhood of GBA, and contribute to the knowledge of the epidemiological situation in the region. In June 1998, potentially infested places were entomologically evaluated. T. infestans was only detected in a hen building for egg production, which housed approximately 6,000 birds. A total of 2,930 insects were collected. Density was about 9 triatomines $/ \mathrm{m}^{2}$. The proportions of fifth instar nymphs and adults were significantly higher than those of the other stages $(p<0.001)$. The number of triatomines collected largely exceeded the highest domestic infestation found in one house from rural endemic areas of Argentina. Though triatomines were negative for Trypanosoma cruzi, they could acquire the parasite by coming in contact with infected people living in GBA. Besides, the numerous and widely distributed places housing hens and chickens, would favor the settlement of the vector. Together, both facts may constitute a risk of parasitic vectorial transmission.

It is recommended to intensify systematic activities of vector search and case detection in GBA.

Key words: Triatoma infestans - hens - urban triatomine foci - Greater Buenos Aires - Argentina

Chagas disease is the most important endemic antropo-zoonosis in Argentina, regarding that over 2 million people are infected by Trypanosoma cruzi (Segura et al. 1985). Triatoma infestans, the main vector, is found in rural, urban and periurban areas (Ronderos \& Schnack 1987). Historically, the areas of highest vectorial transmission were located in north and center of the country (Curto de Casas 1985, Ronderos \& Schnack 1987). Through the South Cone Initiative for the elimination of $T$. infestans, the interruption of $T$. cruzi transmission in the whole country was expected by the year 2000 (Schmunis et al. 1996). Accordingly, the National Chagas disease Control Agency carried out an insecticidal treatment in the dwellings of 19 provinces considered having an intense vectorial transmission (OPS 1997). This campaign did not include the Province of Buenos Aires as it has been occurring from the 60's, at the beginning of the Vector Control Program (Ministerio de Bienestar Social 1977).

\footnotetext{
${ }^{+}$Corresponding author. Fax: +54-11-4576.3384. E-mail: p_gajate@yahoo.com

Received 7 July 2000

Accepted 3 January 2001
}

However, previous studies had shown the existence of vectorial transmission in the Province of Buenos Aires. Carcavallo et al. (1969) found $30 \%$ of houses infested by T. infestans and one acute case of Chagas disease in a neighborhood of Bahía Blanca City. Carcavallo and Plencovich (1973) reported that between 1965 and 1970, 3,407 T. infestans with a T. cruzi infection of $13.7 \%$, were collected throughout the province. In 19 municipalities located in the center and west of the province, Etcheverry (1976) collected 4,935 triatomines showing an infection rate that ranged from 8 to $19 \%$, and reported 15 autochthonous cases. Greater Buenos Aires (GBA), the urban belt surrounding the Federal District, has also been mentioned as infested by $T$. infestans. Carcavallo and Plencovich (1973) informed that $422 T$. infestans $-8.7 \%$ infected by T.cruzi - were mainly found in northeastern municipalities.

The GBA, formed by 19 municipalities, together with the Federal District (Buenos Aires City) constitute the Metropolitan area (Fig. 1). It is an urban agglomeration with undefined limits where in an area of 3,680 $\mathrm{km}^{2}$ live 2,160 inhabitants per $\mathrm{km}^{2}$ (INDEC 1991). The GBA is an important point of social confluence, attracting a continuous flood of migrants from inside and nearby countries, many of which are highly endemic (De Marco et al. 1994). 
Currently, the Health Administration Agencies of many GBA municipalities (e.g. San Martín, La Matanza, General Rodriguez, Luján, Florencio Varela, Fig. 1) receive frequent reports concerning the presence of triatomines (Patricia Gajate, manusc. in prep.). That is the case of La Esmeralda, a neighborhood in the municipality of Florencio Varela (MFV), where many inhabitants have been finding triatomines in their houses since 1983.

The aim of this work was to identify and describe the dispersal foci of $T$. infestans in La Esmeralda neighborhood as well as to contribute to the knowledge of the epidemiological situation in GBA.

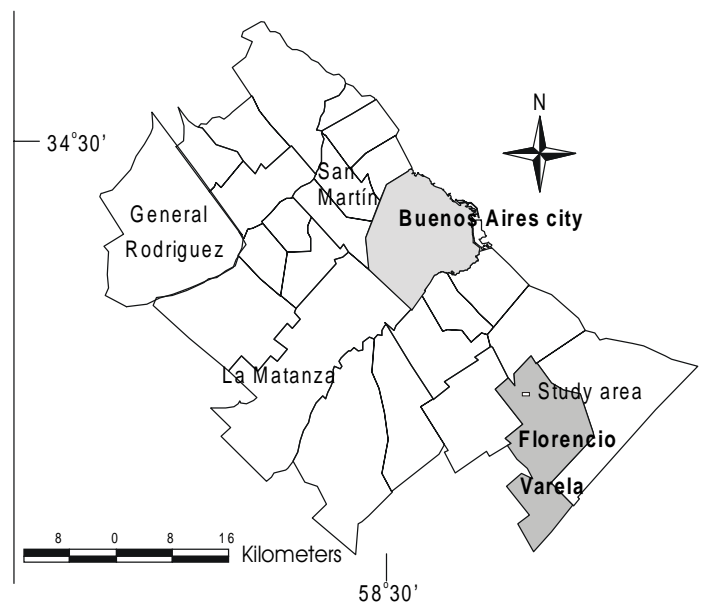

Fig. 1: metropolitan area: Greater Buenos Aires and Federal District, Buenos Aires province, Argentina

\section{MATERIALS AND METHODS}

The climate of GBA is temperate humid, the mean annual RH is $76 \%$ and the mean annual temperature is $15.8^{\circ} \mathrm{C}$ (Estadísticas Climatológicas 1992). During June-July 1998, when the present survey was performed, the minimum, maximum and mean temperatures recorded were $2.4^{\circ} \mathrm{C}$, $22.6^{\circ} \mathrm{C}$ and $13^{\circ} \mathrm{C}$, respectively.

The municipality of Florencio Varela, located in the southeast of GBA $\left(34^{\circ} 50^{\prime} \mathrm{S}, 58^{\circ} 40^{\prime} \mathrm{E}\right.$, Fig. 1 ), has a population of 253,554 inhabitants residing in 65,300 buildings. It shows a low standard of living reflected in poor housing conditions, overcrowded dwellings and a deficient sanitary infrastructure (Ministerio del Interior 1995).

In June 1998, the urban neighborhood La Esmeralda (Fig. 2) was inspected to recognize and carry out an entomological evaluation of the potential $T$. infestans dispersal foci. Sampling places were selected according to their proximity to the domiciles from where triatomines had been reported and the type of productive activities they developed. Thus, places sampled were as follows (Fig. 2): (i) hen building for egg production: it was a shed roofed with fiberglass, occupying a total area of $600 \mathrm{~m}^{2}$. The lower half of the walls was made of bricks covered with cracked concrete, and the upper half was wire mesh. The building harbored approximately 6,000 laying hens. Birds brooded in shelters consisting of six wooden cubes of $1.35 \mathrm{~cm}^{3}$ each, opened at the front and arranged in three rows and two files. Cubes contained wood shaving beds for nesting. When not brooding, hens walked around or roosted near the walls. The proprietor had been running the place for 50 years; he and his family lived in a house five meters away the building; (ii) family chicken house: in a backyard of $6 \mathrm{~m}^{2}$, ten birds were bred in roofed cages made of wood and wire net; (iii) carpentry: it stored numerous logs that came from Entre Ríos in northeastern Argentina, an endemic province for Chagas disease; (iv) commercial rabbit breeding house: 50 rabbits were bred in 30 cages. Twenty metallic cages were inside a shed of $10 \mathrm{~m}^{2}$; the remainder, made of concrete and wire net, were placed outdoors.

A two-person team examined carefully the walls, roofs, animals, goods and furniture present in all areas to detect any sign of triatomine infestation (fecal streaks, exuviae and/or the insect itself). When the place was infested, it was totally sprayed with deltamethrin $\left(0.2 \%\right.$, K-Othrina ${ }^{\circledR}$, Agrevo, Hoechst and Schering) after the temporary removal

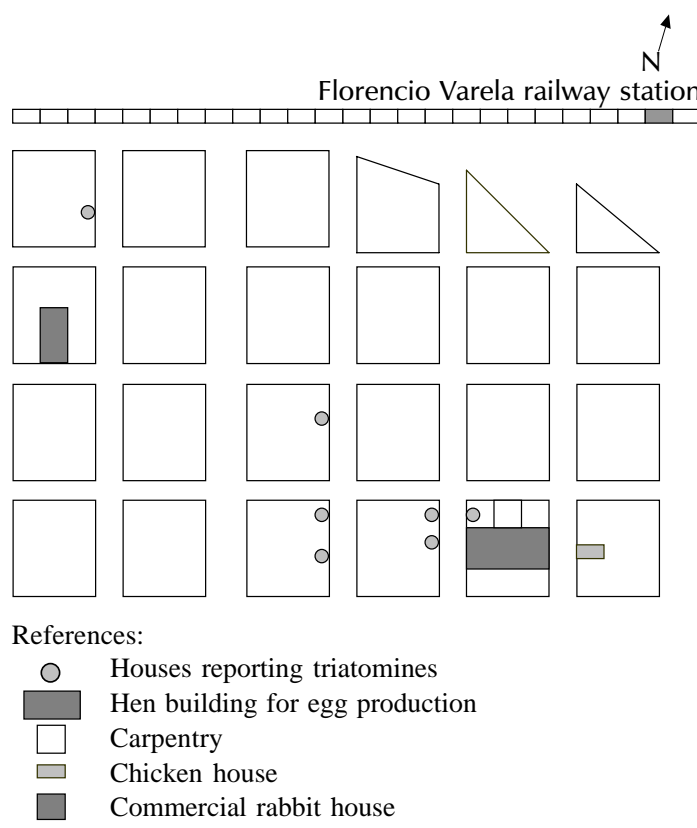

Fig. 2: La Esmeralda neighborhood, Florencio Varela, JuneJuly 1998 
of the domestic animals. All insects that appeared before and after the insecticidal treatment were collected in properly labeled bags and shipped immediately to the laboratory. Triatomines were identified taxonomically (Lent \& Wygodzinsky 1979) and classified according to their developmental stage and sex. T. cruzi infection was determined by the optical microscopic examination of insect feces at $400 \mathrm{x}$ (Wisnivesky-Colli et al. 1982).

The $\chi^{2}$ test was used to compare the proportions of collected nymphs and adults (Fleiss 1981).

\section{RESULTS}

Infestation was only detected in the commercial laying hen building. From a total of 2,930 T . infestans, 1,233 (42\%) were caught mainly from shelters. Insects were hidden in the space left between the back of the shelter and the wall, in the angles of the cubes and inside crevices of the wood. The approximate mean density was 9 triatomines per $\mathrm{m}^{2}$.

The Table shows the T. infestans frequencies of the captured individuals according to developmental stage, sex and place of capture. Due to the magnitude of the place, and the bird and insect abundance, the entomological evaluation and the insecticidal treatment were achieved in four occasions. All stages were present in the colony, and $35 \%$ of the collected insects were adults. The proportions of fifth instar nymphs and adults were significantly higher than those of the other stages ( $\mathrm{p}$ $<0.001$ ), and represented $73 \%$ of the whole collection. The female/male ratio was 1:1. Triatomines were not infected by $T$. cruzi.

When the owner was notified of the extent of infestation, he recognized that he had already seen them in many opportunities. Repeated attempts to evaluate his house failed due to his persistent refusal, in spite of our warning about the health risk involved. In order to examine the area near the focus, it was required a meeting between neighbors and us, that should be arranged by the Neighborhood Society. Unfortunately, its committee is still avoiding the meeting by reasons external to this study.

Three months later, only $12 \mathrm{~T}$. infestans were found after a second entomological evaluation, and the building was sprayed again with deltamethrin.

In December 1998, the chicken house was shut down and birds were removed, but our recommendation of burning nests and other goods was disregarded. Since then, no further reports on triatomine presence were received from the neighborhood.

\section{DISCUSSION}

In this work, we notify the presence of almost 3,000 vectors of Chagas disease in an urban area of a densely populated municipality. The large number of $T$. infestans individuals found during the winter in La Esmeralda neighborhood, remarkably exceeded the highest domestic infestation recorded in one house during the warm seasons of any studied rural endemic area. For example, in the Province of Santiago del Estero, Argentina, the maximum number of T. infestans found in the walls and beds of a rural house was 305 individuals (Rabinovich et al. 1990). In addition, this house showed half the population density found in the hen building ( 4.5 and 9 triatomines $/ \mathrm{m}^{2}$, respectively). Therefore, our results suggest that the chicken house provided suitable requirements of shelter and blood meal for the development of a high density T. infestans population, in spite of the low winter temperatures. This fact together with the reports from nearby houses on the presence of $T$. infestans during the last 15 years would indicate that it was a long standing focus and an important dispersal source.

Though triatomines were not infected by $T$. cruzi, presumably because they had fed on bird, they could acquire the parasite by coming in contact with infected people. Rosenstein-Campanini

\section{TABLE}

Nymphs and adults of Triatoma infestans collected in a commercial laying hen building. June and July 1998, La Esmeralda, municipality of Florencio Varela, Greater Buenos Aires, Argentina

\begin{tabular}{|c|c|c|c|c|c|c|c|c|}
\hline \multirow[b]{3}{*}{ Sampling date } & \multicolumn{7}{|c|}{ Triatoma infestans } & \\
\hline & \multicolumn{3}{|c|}{ Adults } & \multicolumn{5}{|c|}{ Nymphs } \\
\hline & Males & Females & Total (adults) & N5 & $\mathrm{N} 4$ & N3-2-1 & Total (nymphs) & Total \\
\hline Jun-29 & 73 & 90 & 163 & 96 & 3 & 45 & 144 & 307 \\
\hline Jul-6 & 222 & 214 & 436 & 527 & 180 & 189 & 896 & 1,332 \\
\hline Jul-13 & 91 & 52 & 143 & 336 & 119 & 175 & 630 & 773 \\
\hline Jul-20 & 99 & 177 & 276 & 160 & 50 & 32 & 242 & 518 \\
\hline Total & 485 & 533 & 1,018 & 1,119 & 352 & 441 & 1,912 & 2,930 \\
\hline$(\%)$ & & & $(35)$ & $(38)$ & $(12)$ & $(15)$ & & $(100)$ \\
\hline
\end{tabular}


et al. (1992), reported that the infection prevalence of GBA inhabitants was $5 \%$, the percentage was calculated considering approximately 400,000 infected people from 8,000,000 GBA inhabitants recorded in the last population census (INDEC 1991), as high as the one recorded in provinces where vectorial transmission usually takes place. Even if most of the seropositive people living in GBA were in the chronic phase of the disease, the number of their blood trypomastigotes should be enough to infect a considerable proportion of triatomines. In a research performed by Schenone et al. (1972) with 764 chronic patients, $49.3 \%$ of all the xenodiagnosis boxes turned positive. Because every patient received one box containing between 7 to $10 T$. infestans nymphs and the insects from each box were examined together, we arrive at the conclusion that $49.3 \%$ of the patients could infect at least one triatomine. Moreover, Cerisola et al. (1974) found that 30 chronic patients were able to infect a minimum of 1,424 triatomines, at the end of a 3-year longitudinal study.

On the other hand, the close association between $T$. infestans and domestic birds has been fully demonstrated (Gajate et al. 1994, Vallvé et al. 1995). Therefore, the presence of numerous and widely distributed places where chickens and hens are gathered may constitute an advantageous condition for the settlement of the vector in GBA.

The results reported here, together with the detection of other scattered foci in different municipalities, indicate the need of intensive and systematic activities of vector search and case detection to demonstrate the actual vectorial transmission occurrence in GBA.

\section{ACKNOWLEDGEMENTS}

To Luciana Piudo, Jorge Pérez, Víctor Martínez, Lorenzo Guzmán, Marcelo Heredia and Oscar Pedraza for technical assistance.

\section{REFERENCES}

Carcavallo RU, Plencovich AR 1973. La enfermedad de Chagas en la Provincia de Buenos Aires, Argentina. Bol Of Sanit Panam 14: 281-289.

Carcavallo RU, Blaksley JC, Rubin de Celis M, Marcilese E, Laspiur J 1969. Enfermedad de Chagas: estudio epidemiológico de un foco. Tribuna Médica 12: 327-328.

Cerisola JA, Romwedder RR, Segura EL, Del Prad CE, Alvarez M, Wynne Martini GS 1974. El Xenodiagnóstico, Ministerio de Bienestar Social, Secretaria de Estado de Salud Pública, Buenos Aires, $127 \mathrm{pp}$.

Curto de Casas SJ 1985. Problemática geográfica de la endemia chagásica y técnicas para su estudio. In $\mathrm{R}$ Carcavallo, J Ravinovich, R Tonn (eds), Factores Biológicos y Ecológicos en la Enfermedad de
Chagas, Ministerio de Salud y Acción Social, Argentina, p. 31-47.

De Marco GM, Rey Balmaceda RC, Sassone SM 1994. Extranjeros en la Argentina, Pasado, Presente y Futuro, Programa de Investigaciones Geodemográficas, CONICET, Tomo II, $568 \mathrm{pp}$.

Estadísticas Climatológicas 1981-1990. Ser B6: 37, 1992, Fuerza Aérea Argentina.

Etcheverry D 1976. Enfermedad de Chagas. Provincia de Buenos Aires. Sem Med 149: 444-448.

Fleiss JL 1981. Statistical Methods for Rates and Proportions, 2nd ed., John Wiley \& Sons, New York, $255 \mathrm{pp}$.

Gajate PP, Bottazzi MV, Pietrokovsky SM, WisniveskyColli C 1994. Relação entre Triatoma infestans, aves domésticas e o homem num povoado de Santiago del Estero, Argentina. Cad Saúde Públ 10: 53-57.

INDEC-Instituto Nacional de Estadística y Censos 1991. Secretaria de Planificación. Censo Nacional de Población y Vivienda, República Argentina.

Lent H, Wygodzinsky P 1979. Revision of the triatominae (Hemiptera, Reduviidae) and their significance as vectors of Chagas' disease. Bull Am Mus Nat Hist 163: 123-520.

Ministerio de Bienestar Social 1977. Programa Nacional de Lucha contra la Enfermedad de Chagas. Informe Técnico 1977, Secretaría de Estado de Salud Pública, Argentina.

Ministerio del Interior 1995. Comisión Nacional Area Metropolitana de Buenos Aires. El Conurbano Bonaerense, relevamiento y análisis, p. 218.

OPS-Organización Panamericana de la Salud 1997. Iniciativa del Cono Sur, VI Reunión de la Comisión Intergubernamental para la eliminación de Triatoma infestans y la interrupción de la transmisión de la tripanosomiasis americana por transfusión. Santiago, Chile, OPS/HPC/HCT/98. 102, 83 pp.

Rabinovich JE, Wisnivesky-Colli C, Solarz ND, Gürtler RE 1990. Probability of transmission of Chagas disease by Triatoma infestans (Hemiptera: Reduviidae) in an endemic area of Santiago del Estero, Argentina. Bull WHO 68: 737-746.

Ronderos RA, Schnack JA 1987. Ecological aspects of triatominae in Argentina. In RR Brenner, A Stoka (eds), Chagas' Disease Vectors, CRC Press, Inc., USA, p. 85-97.

Rosenstein-Campanini A, Blanco S, De Rissio AM, Lansseti JC, Lauricella ME, Segura EL 1992. Transmisión de Trypanosoma cruzi por transfusiones de sangre. In R Madoery, C Madoery, MI Cámera (eds), Actualizaciones en la Enfermedad de Chagas, Organismo Oficial del Congreso Nacional de Medicina, Argentina, p. 237-241.

Schenone H, Alfaro E, Rojas A 1972. Bases y rendimiento del xenodiagnóstico en la infección chagásica. Simposio Internacional sobre Enfermedad de Chagas, Sociedad Argentina de Parasitología, Buenos Aires, p. 111-114.

Schmunis GA, Zicker F, Moncayo A 1996. Interrupción de la transmisión de la enfermedad de Chagas a través de la eliminación del vector. Lancet 384: 1171.

Segura EL, Pérez AC, Yanovsky JF, Adrade J, Wyne de 
Martini GJ 1985. Decrease in the prevalence of infection by Trypanosoma cruzi (Chagas' disease) in young man of Argentina. Bull WHO 10: 252-264.

Vallvé SL, Rojo H, Wisnivesky-Colli C 1995. Ecología urbana de Triatoma infestans en Argentina. Asociación entre Triatoma infestans y palomares.
Rev Saúde Pública 29: 192-198.

Wisnivesky-Colli C, Gürtler RE, Solarz ND, Salomón D, Ruiz AM 1982. Feeding patterns of Triatoma infestans (Hemiptera, Reduviidae) in relation to transmission of American trypanosomiasis in Argentina. J Med Entomol 19: 645-654. 
T. infestans in Buenos Aires - P Gajate et al. 